\title{
New Discoveries at Tell el-Farkha and the Beginnings of the Egyptian State
}

\author{
Krzysztof M. CiaŁowicz
}

\begin{abstract}
Tell el-Farkha was an important centre already in Predynastic times, when a great Lower Egyptian culture complex was erected on the Central Kom. Items found inside confirmed both the significant role played by the local elite and its relationship with the Levant and Upper Egypt. The first large Naqadian building was erected outside the town centre. This building and the whole settlement were destroyed (Naqada IIIA1) by the next group of Naqadians, probably connected with another political centre. They were the constructors of the oldest Egyptian mastaba. During the reign of Iry-Hor (middle of Naqada IIIB), the third group of Naqadians appeared at the site. The period between Naqada IIIA and middle of IIIB phase seems to have been a period of competition between the most influential Naqadian proto-kingdoms. In the middle of the First Dynasty, Tell el-Farkha changed its role: from the capital of a part of the Eastern Delta to a provincial town of only economic significance.
\end{abstract}

Keywords: Lower Egyptian culture, Naqada culture, Protodynastic Egypt, Early Dynastic Egypt, Tell el-Farkha

Krzysztof M. Ciałowicz, Institute of Archaeology, Jagiellonian University, Kraków; kmcialowicz@interia.pl

Tell el-Farkha is located next to the northern outskirts of the village of Ghazala, along the southern side of the Ghazala Drain, about $14 \mathrm{~km}$ east of El-Simbillawein. The site occupies an area of about $45,000 \mathrm{~m}^{2}$, with a maximum height of $c .4 .5 \mathrm{~m}$ above the level of the cultivation plain. The site is actually marked by three mounds along the northern edge of the gezira and a gentle slope delimited by the village houses to the south and east. It is possible that the site was originally larger than today, stretching southwards beyond the current houses.

The site was discovered by the Italian Archaeological Mission in the Eastern Nile Delta in 1987. An Italian expedition, directed by R. Fattovich, carried out test excavations at the site between 1988-1990, although the works were later halted. ${ }^{1}$ In 1998 , the excavations

\footnotetext{
${ }^{1}$ Chłodnicki, Fattovich, Salvatori 1991; 1992.
} 
at Tell el-Farkha, thanks to the kind permission of their Italian colleagues, were resumed by the Polish Archaeological Mission to the Nile Delta. ${ }^{2}$ After a few years of Polish excavations seven main chronological phases were distinguished (Tab. 1).

Tab. 1. The main chronological phases at Tell el-Farkha

\begin{tabular}{|c|l|c|l|}
\hline $\begin{array}{c}\text { Tell } \\
\text { el-Farkha } \\
\text { phase }\end{array}$ & \multicolumn{1}{|c|}{ Relative chronology } & \multicolumn{1}{|c|}{$\begin{array}{c}\text { Absolute } \\
\text { chronology }\end{array}$} & \multicolumn{1}{|c|}{ Southern Levant } \\
\hline 1 & Naqada IIB-C & c. $3700-3500$ & Early Bronze IA2 \\
\hline 2 & Naqada IID1 & c. $3500-3450$ & Early Bronze IA2 \\
\hline 3 & Naqada IID2/IIIA1 & c. $3450-3350$ & Early Bronze IB (early) \\
\hline 4 & Naqada IIIA1-IIIB & c. 3350-3200 & Early Bronze IB (middle) \\
\hline 5 & $\begin{array}{l}\text { Naqada IIIB-IIIC1 } \\
\text { (Dynasty 0 - middle of the First Dynasty) }\end{array}$ & $c .3200-3000$ & Early Bronze IB (late) \\
\hline 6 & $\begin{array}{l}\text { Naqada IIIC1-IIID } \\
\text { (middle of the First - Second Dynasty) }\end{array}$ & $c .3000-2700$ & Early Bronze II \\
\hline 7 & Third - Fourth Dynasty & $c .2700-2600$ & Early Bronze II \\
\hline
\end{tabular}

During the surveys made in the north-eastern Nile Delta ${ }^{3}$ numerous sites were discovered very near one another, including Tell el-Farkha and Tell el-Murra, which have also been excavated by the Polish team for several seasons. ${ }^{4}$ In an area so thickly populated, one should expect at least one important centre. So far, Tell el-Farkha seems to be the best candidate.

From the beginning of its occupation, the importance of Tell el-Farkha is very clear and the prosperity of the inhabitants was connected not only with agriculture and animal breeding. This is proved by the so-called Lower Egyptian residence from the Central Kom. ${ }^{5}$ This spacious structure was separated from the rest of the settlement by wooden fences (at least $20 \times 25 \mathrm{~m}$ ). Inside, was an edifice with a complex interior. This construction differs from the small and simple single houses found in other parts of Tell el-Farkha, as well as those known from other sites. ${ }^{6}$ In the period contemporaneous with Naqada IIC the wooden fences were replaced by solid mud-brick walls, but inside a traditional wattle-and-daub architecture continued.

The Lower Egyptian residence has yielded many important artefacts. Twenty percent of Near Eastern pottery from the Central Kom discovered thus far has been found in Tell el-Farkha phase 1 (Lower Egyptian occupation), and the next twenty percent of pottery

\footnotetext{
2 Chłodnicki, Ciałowicz, Mączyńska (Eds) 2012.

3 Cf. p.ex. Brink 1988; Jucha, Buszek 2011.

4 Jucha 2013; Jucha et al. 2016.

5 Chłodnicki, Geming 2012: 92-98.

${ }^{6}$ Cf. p.ex. Rizkana, Seeher 1989: 39ff.
} 


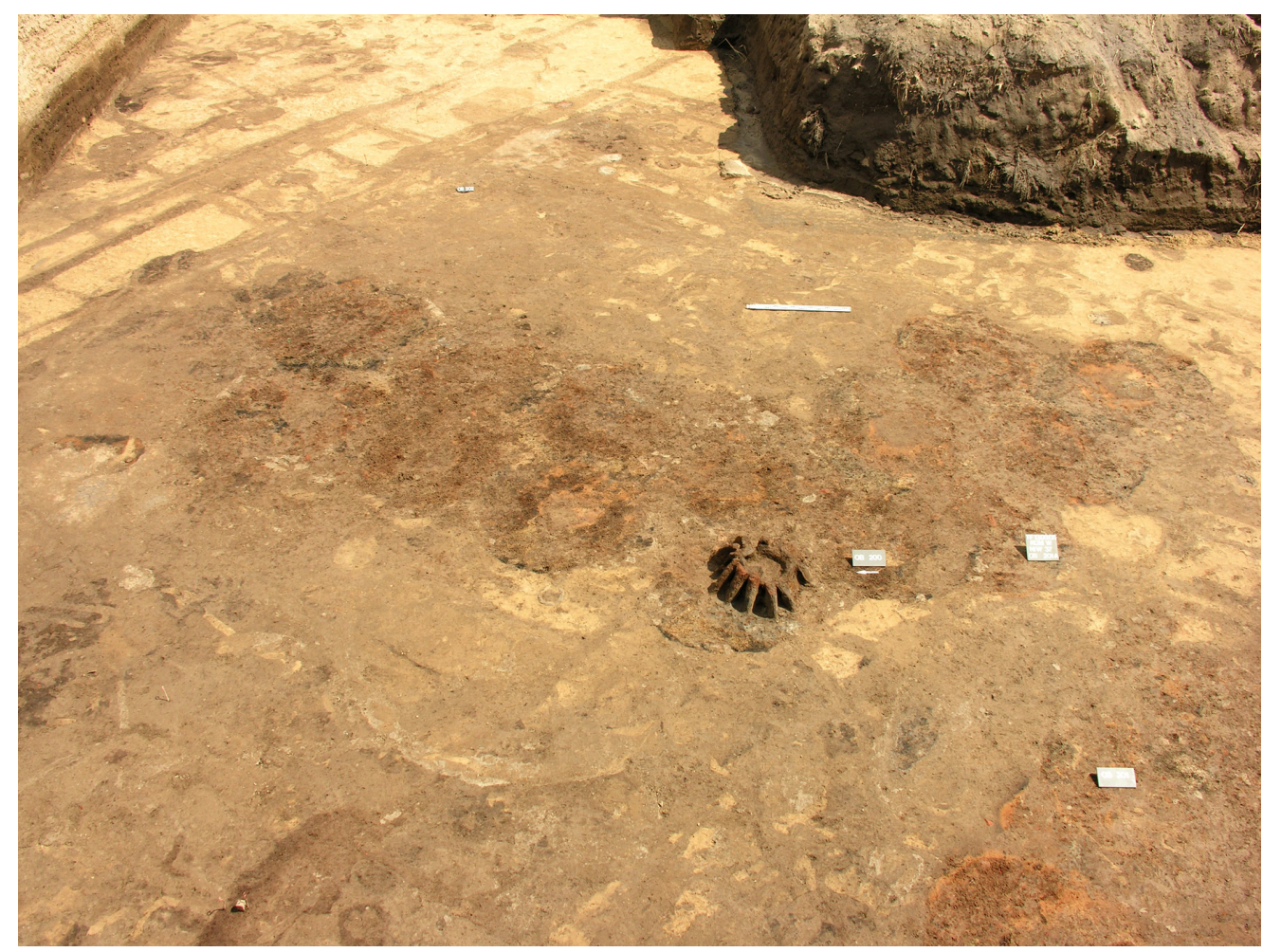

1. The oldest brewery from Western Kom; remains of wooden fences visible on the top (Phot. R. Słaboński).

imports are dated to phase 2 (transitional between Lower Egyptian and Naqada cultures). ${ }^{7}$ The layers linked with phase 1 also produced the oldest copper object at Tell el-Farkha. This is a knife, very similar to the specimen discovered at the Ashqelon-Barnea (Israel). ${ }^{8}$ Such an abundance of Near Eastern imports is not surprising given that from the beginnings of studies on Lower Egyptian culture its strong relations with the Levant have been evident. ${ }^{9}$

More important is the evidence of much closer connections with Upper Egypt. Besides the pottery fragments, the most important is the necklace, or other personal adornment, made from various stones ( 23 beads) and gold ( 4 beads). Two pear-shaped mace-heads, from the few discovered, are also worth mentioning. One is made from basalt and was evidently used. The second is made from bone and should be treated as a symbol of power. Also a greywacke palette in the form of a fish, some stone vessels and flint knives should be considered as imports from the South. It is worth stressing that outside of the Lower Egyptian residence no valuable imported items were uncovered. ${ }^{10}$ Such distribution of imports confirms that the place was inhabited by the local elite.

\footnotetext{
${ }^{7}$ Czarnowicz 2012a: 257.

8 Czarnowicz 2012b: 351.

${ }^{9}$ Cf. p.ex. Seeher 1990.

${ }^{10}$ Chłodnicki, Geming 2012: 97-98.
} 


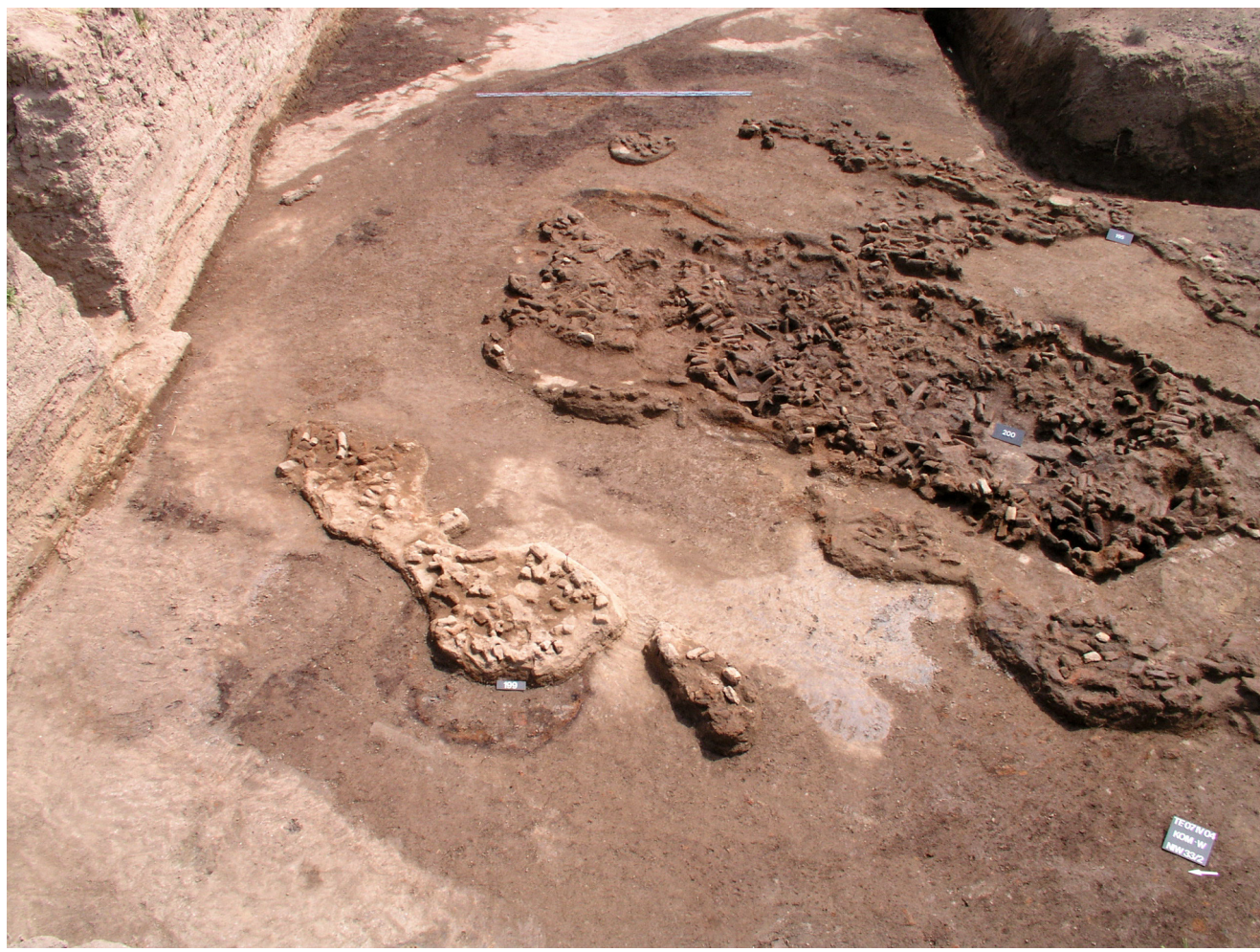

2. The brewery from Naqada IIC surrounded by mud-brick walls (Phot. R. Słaboński).

During the Lower Egyptian culture a brewery centre was established at the Western Kom. The oldest (Naqada IIB) structure discovered thus far consisted of 13 sockets (Fig. 1) in which vats were installed. ${ }^{11}$ The entire production area was surrounded by wooden fences, separating the breweries from the ordinary houses. The wooden fences were very soon (Naqada IIC) replaced by mud-brick walls (Fig. 2). It is evident that beer production was under the control of local elites, who probably exported at least part of the products. This is evidenced also by the first tokens which appeared in this area during Tell el-Farkha phase 1 (Naqada IIB-C).

We can state that from the beginnings of the occupation at Tell el-Farkha, Lower Egyptian society was much more stratified than has been to date supposed. At the top was the local elite, which can be compared with the Upper Egyptian nobles, and the stratification of Lower Egyptian society is visible in the settlements, and not in the cemeteries, as it is in the South. The elite probably controlled many aspects of life, trade with the East and South, among others. Moreover we can suppose that the basis for commercial relations between Egypt and the Near East was established by the Lower Egyptians.

11 Ciałowicz 2012a: 151. 


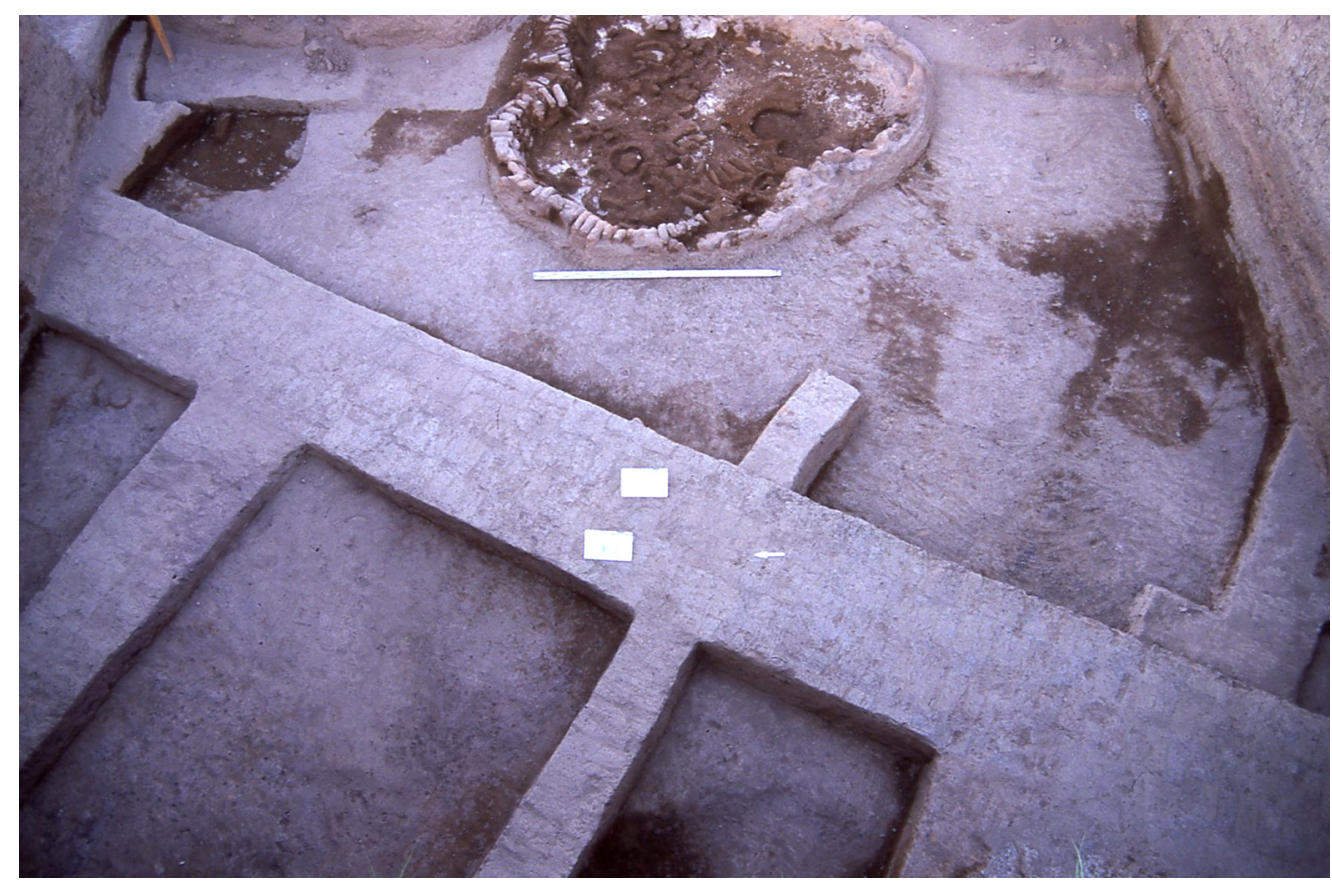

3. Eastern wall of the oldest stage of Naqadian residence; small brewery in the background (Naqada IID1 period) (Phot. R. Słaboński).

In effect, the Naqadian settlers at Tell el-Farkha had a clear path to raising social relations to a higher level.

During Tell el-Farkha phase 2 (Naqada IID1) the breweries at the Western Kom and the Lower Egyptian residence on the Central Kom were destroyed by high flooding of the Nile with the entire area covered with mud. The residence was quickly rebuilt. To the east, in a place formerly occupied by houses, a small brewery was established.

It seems very likely that the increased contacts between Delta and Upper Egypt required the permanent presence of a representative of Naqada culture in Tell el-Farkha. Therefore, Lower Egyptian authorities allowed the first huge Naqada building to be erected in the destroyed area, in a location previously occupied by breweries, i.e. outside the Lower Egyptian town centre, where local elites continued to reside.

The Naqada residence at the Western Kom was erected on a layer of mud (Fig. 3). To the east of it a small brewery was established, which initially led to the supposition that the beer produced there was used by the inhabitants of the Naqadian building, just as the beer from the brewery at the Central Kom served the needs of the Lower Egyptian elite.

The discoveries made in a few last seasons have allowed us to consider other explanations. Beneath the walls connected with the Proto- and Early Dynastic administrative- 
-cultic centre ${ }^{12}$ a pit of an almost red colour was discovered. During the exploration it became evident that it was another brewery (W272). It had at least three distinct phases of use (Fig. 4). The most recent is dated to Naqada IIIA1. It was clearly younger than the Naqada residence and older than the administrative-cultic centre. Between the middle and most recent phases, a thick layer composed of burnt soil and white ash was recognised (Fig. 5). In previously discovered breweries, ${ }^{13}$ ash was usually almost completely removed during the reconstruction, rebuilding or when a new structure was being erected in the same place. In the newly discovered brewery the layer of destruction is quite thick (up to $15 \mathrm{~cm}$ ) and looks like the remains of intentional levelling. It was probably done following a catastrophic fire. The fact that the brewery was rebuilt in the same place led to the formulation of a new hypothesis. Namely: possibly this brewery, as well as the above-mentioned brewery connected with the oldest stage of the Naqada building activity and the one from the Central Kom, were established during the construction of the huge complexes and the beer produced in them should be treated as a supply for employed workers. This would generally mean that in Lower Egyptian and Naqadian societies the organisation of work had to be at a much higher level than was previously supposed.

The above-mentioned Naqada residence is the biggest Naqadian building excavated to date in Egypt. It was rebuilt several times and the oldest phase had a simple layout. This huge complex was built on the top of the Kom and was surrounded with thick mud-brick walls $(1.40-1.60 \mathrm{~m})$, although only the eastern one has been unearthed in its full length (almost $24 \mathrm{~m}$ ). Inside the building, the remains of poorly preserved rooms have been recognised. Most of them were small, surrounded by $30-40 \mathrm{~cm}$ wide walls. It is than possible that the main function of the thick outside walls was separation of this complex from the rest of the settlement or perhaps they should even be treated as defensive walls. In some of the internal rooms, storage jars and a large concentration of potsherds were discovered. One of these jars had characteristic wavy handles and was made of non-Egyptian clay. Undoubtedly it was imported from the southern Levant. ${ }^{14}$ All these data (the form and dimensions of the rooms, the presence of the storage jars, imports among them) suggest that the mentioned rooms were warehouses.

The edifice was rebuilt very quickly. The size of the most recent structure may be described as monumental. The internal layout and the dimensions of the whole building are well visible in the lower strata containing the remains of the complex related to the times of its maximum extent and splendour. An internal courtyard was enclosed by several rooms. The monumental dimensions of the edifice are particularly significant, as it covered an area of over $500 \mathrm{~m}^{2}$. Huge mud-brick walls $(1-2.5 \mathrm{~m}$ wide) enclosed most of the compartments.

\footnotetext{
12 Ciałowicz 2011a.

13 Ciałowicz 2012a: 149-162.

14 Czarnowicz 2012a: 245.
} 


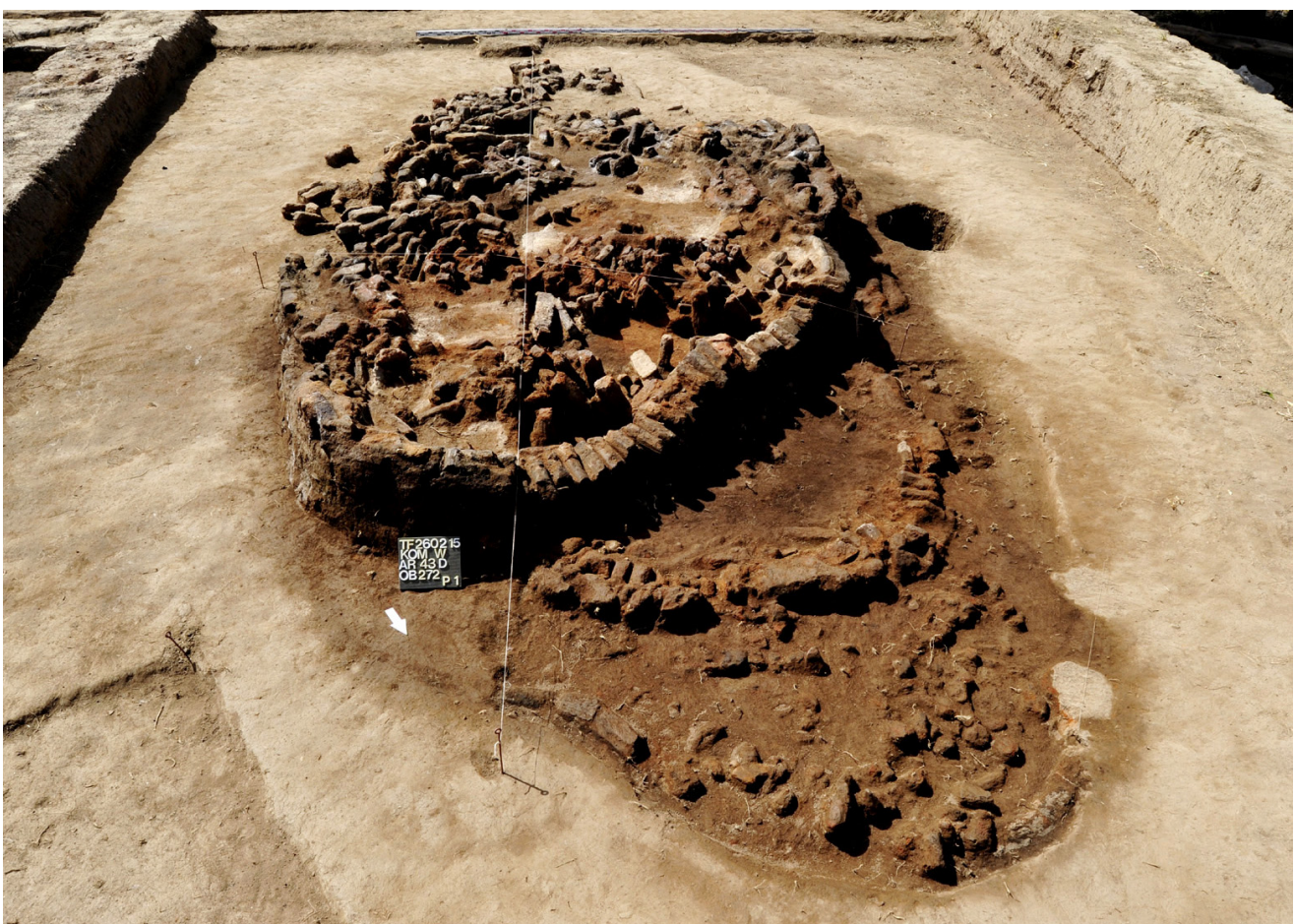

4. The brewery W272; three phases of use (Phot. R. Słaboński).

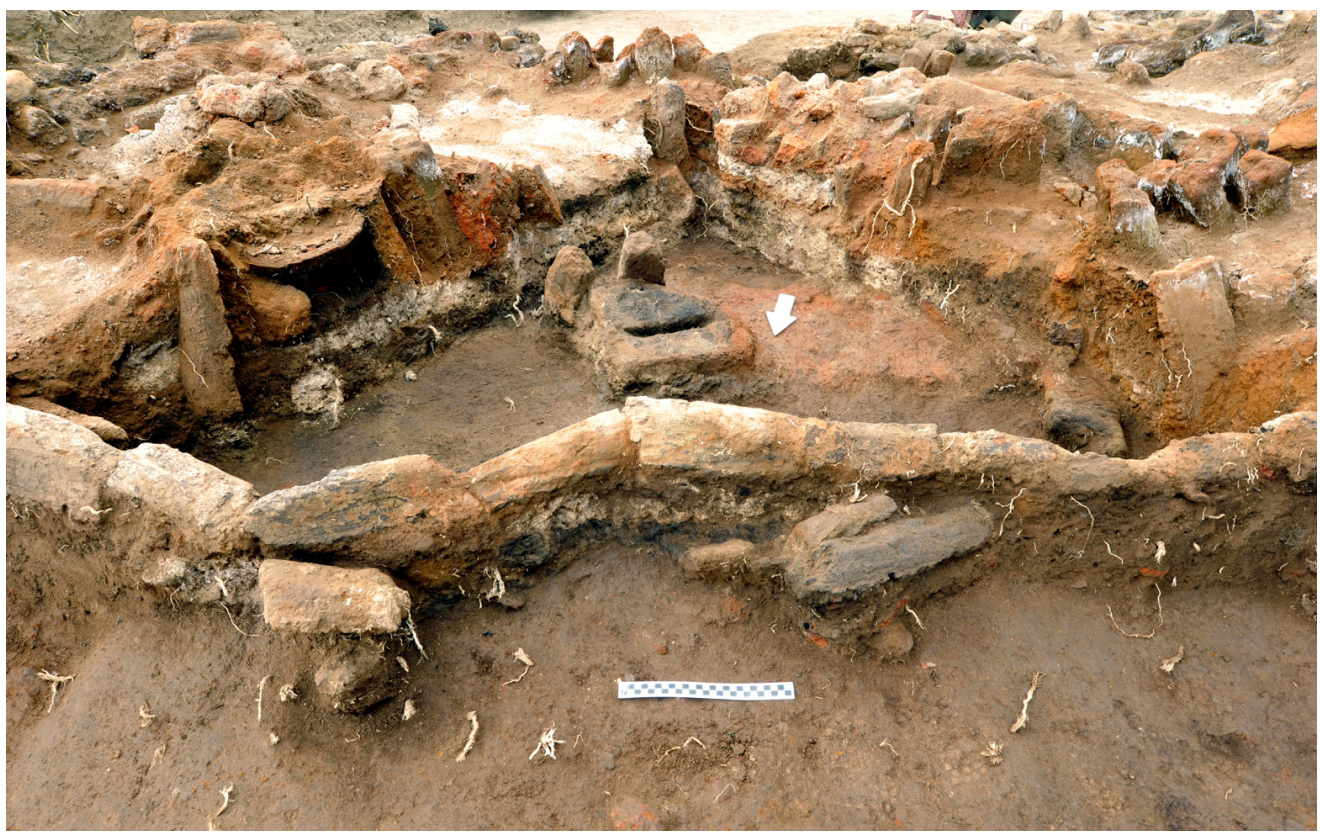

5. A layer of burnt soil and white ashes between middle and the most recent phases of the brewery W272 (Phot. R. Słaboński). 


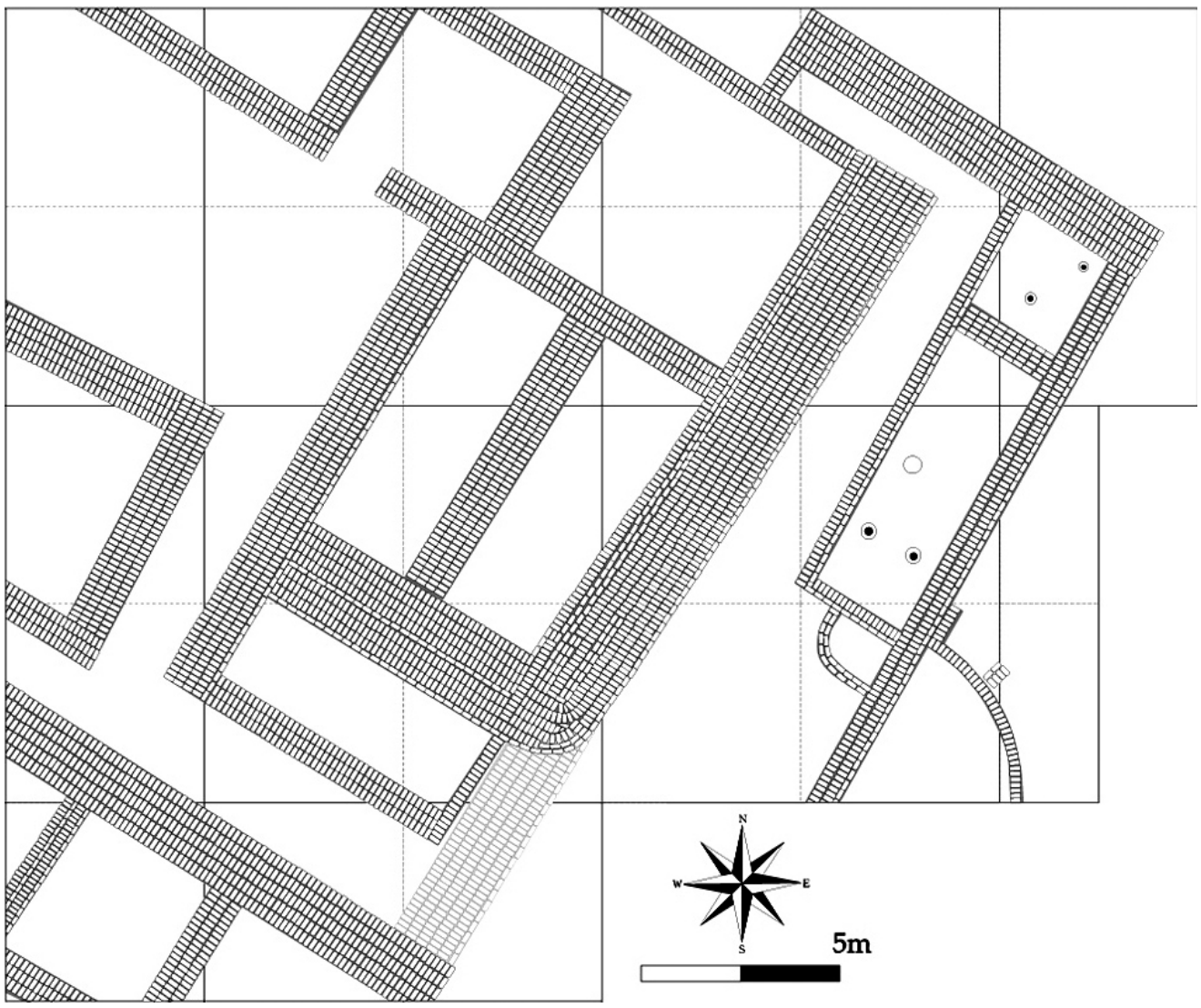

6. The most recent phase of Naqadian residence (Naqada IIIA1 period) (Drawing: M. Czarnowicz).

The reason for which the complex, at the beginning of Naqada IIIA1, was once again rebuilt and enlarged remains unknown. It consisted then of two clearly different parts, separated by a $2.5 \mathrm{~m}$-thick wall (Fig. 6). At the southern extreme it ends with a big rounded corner. The regular arrangements of mud-bricks marked a clearly visible outline of a few rooms forming the western part of the building. The eastern one consists of small rooms, which yielded a considerable concentration of small finds and storage vessels, found standing in their original position. The evidence clearly points to a sudden abandonment of the complex and suggests that its eastern section served as store-houses.

Another concentration of vessels was recorded at the western end of the Kom, evidently connected with the described phase of the building. A similar situation can be seen at the southern extreme of the excavated area. Probably the main rooms of the Naqada building were surrounded by magazines, at least on the eastern, western and southern sides.

Apart from storage vessels, in this building plain seals and cylinders impressions were also represented, as well as tokens in the form of balls and discs. Here, but also in other places of the settlement, fragments of pottery of Southern Levantine origin were 


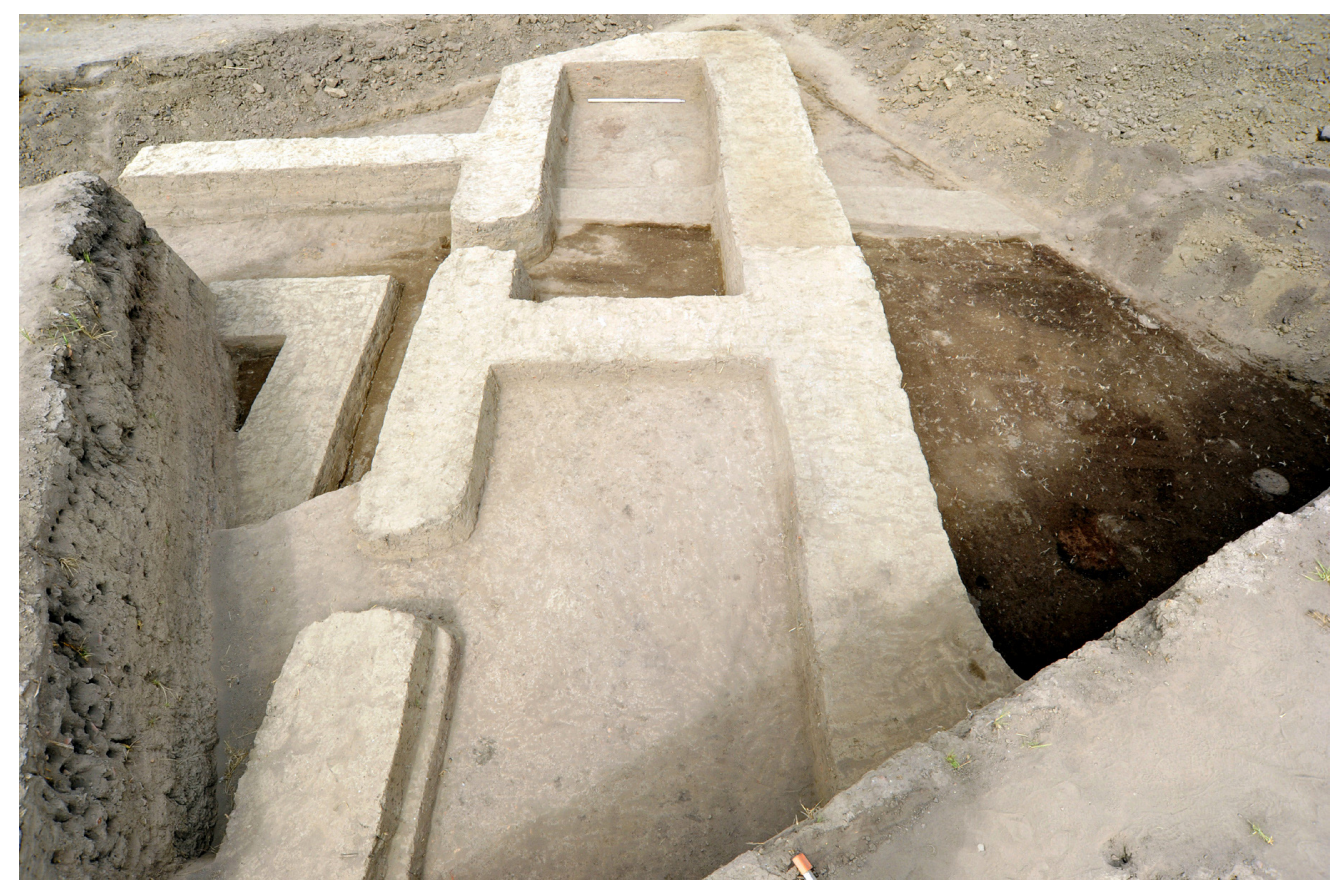

7. Older phase of Naqadian storage from the Central Kom (Naqada IIIA1 period); view from the south (Phot. R. Słaboński).

discovered. It is worth stressing that they included potsherds typical for Early Bronze IB Erani C Horizon, ${ }^{15}$ attested at Tell el-Farkha from the beginning of our phase 3 until the middle of phase 4 (end of Naqada IIIA).

The later phase of the Naqadian residence is connected to another monumental edifice (c. $25 \times 15 \mathrm{~m}$ ), discovered at the Central Kom. This building (Fig. 7) most probably played the role of protecting central storage facilities and had at least two phases of usage - the older, erected at the beginning of the Naqada IIIA1, and a more recent one - dated to Naqada IIIA1-IIIA2, ${ }^{16}$ contemporaneous with the first stage of the administrative-cultic centre. ${ }^{17}$

The Naqada residence was burnt down during the first half of Naqada IIIA1 (Fig. 8). Probably all constructions at the Western Kom were destroyed in the same time. This is proved by the above-described layer separating the most recent and middle phases of brewery W272 and the thick burnt stratum that is very clearly attested in the profiles in this part of the site. A similar layer of destruction was recognised also between older and more recent

\footnotetext{
15 Czarnowicz 2012a: 247.

16 Chłodnicki, Ciałowicz 2016: 232.

${ }^{17}$ Ciałowicz 2012b: 171-175.
} 


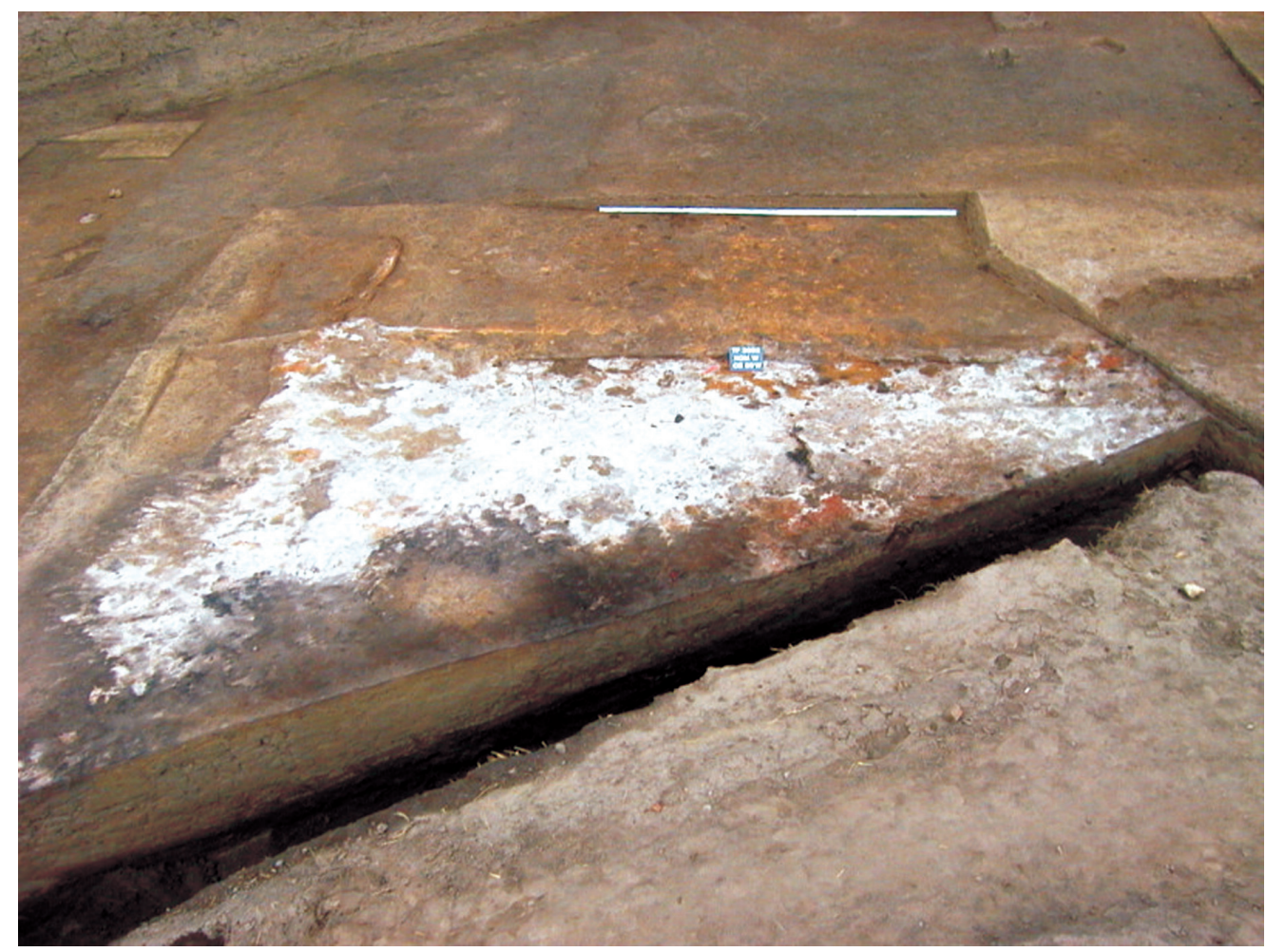

8. Burnt layer on top of Naqadian residence (Phot. R. Słaboński).

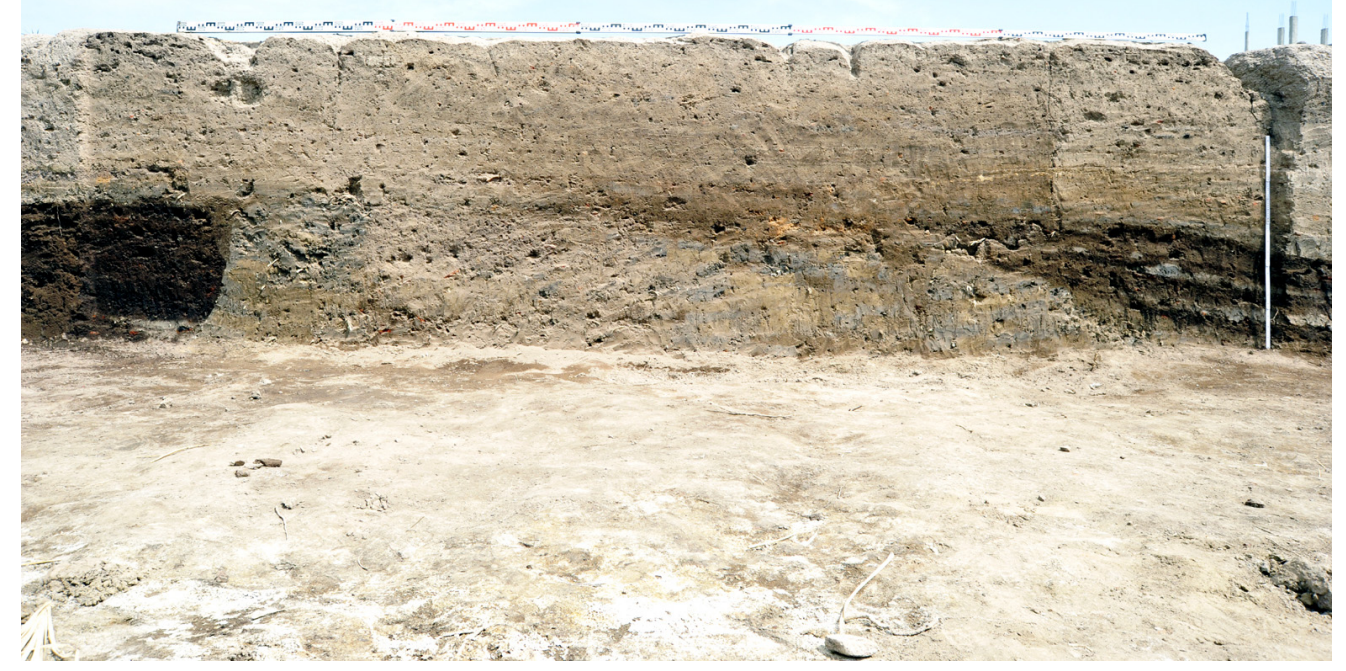

9. Destroyed room and the burnt layer extending north and south of it; view from the west (Phot. R. Słaboński). 
stages of the Naqadian storage house from the Central Kom. The fire could have been started accidentally or as a result of a local natural disaster, for instance an earthquake. But it should also be taken into consideration that it could have been the result of intentional action. The latter supposition is confirmed by the situation recorded at the Eastern Kom at Tell el-Farkha. In a small test trench at the edge of the Kom an important mud-brick structure was discovered. ${ }^{18}$ It is dated to phase 3 of Tell el-Farkha (Naqada IID2/IIIA1), and was founded directly on the sands of the gezira. The walls were $c .1 .0 \mathrm{~m}$ thick and formed a rectangular room $(c .2 .50 \times 6 \mathrm{~m})$ with two entrances.

On the southern extreme of the main trench, about $30 \mathrm{~m}$ to the west from the described construction, another mud-brick wall (also founded on the gezira) was unearthed. It is oriented in a similar manner to the first building and they were probably parts of the same edifice. In the southern part of the Eastern Kom no structures of Lower Egyptian culture were discovered. It is then possible that all the described constructions are relicts of the oldest Naqadian settlement erected in these place, at the same time as the Naqadian residence at Western Kom.

During the 2015 season, grave no. 130 was explored. ${ }^{19}$ It was built on a wall also belonging to the oldest Naqadian settlement. The same wall can be seen (approximately $20 \mathrm{~m}$ to the west) in the profile of the trench. It forms the southern border of a rectangular room. The northern wall of this room is also clearly discernible. The space between them looks like a heap of destroyed bricks (Fig. 9).

All these mentioned constructions were evidently destroyed and covered by a thick burnt layer. The date of this disaster is the same as the fatal end of the Naqada residence - Naqada IIIA1. We can thus suppose that the entire settlement at Tell el-Farkha was destroyed as a result of human action during this period. One should remember that at the same time the emergence of the earliest proto-kingdoms in Upper Egypt can be assumed. It is enough to mention the large and well equipped graves from Abydos and Hierakonpolis, ${ }^{20}$ and the ceremonial centre from the latter site. ${ }^{21}$ It is very likely that both centres were competing in various fields. The dominant issue could have been control over the trade routes to the Levant. We can also presume that the first Naqadian settlers at Tell el-Farkha, the builders of the Naqada residence, originated from a different centre than their successors.

The second group of Naqadians still maintained trade with the Near East, but their relations were not restricted to the Southern Levant. They reached to the Northern Levant, at least to Megiddo, as is proved by pottery discovered at Tell el-Farkha. ${ }^{22}$ This group of people should also be regarded as the builders of the oldest stage of the administrative-cultic centre at the Western Kom (see above) and the mastaba at the Eastern one. The mastaba, dated to

\footnotetext{
18 Ciałowicz, Dębowska-Ludwin 2013a: 29.

19 Chłodnicki, Ciałowicz 2016: 247.

${ }^{20}$ Dreyer, Hartung, Pumpenmeier 1993; Dreyer et al. 1996; Adams 1996; Friedman 2008.

${ }^{21}$ Friedman 2009.

${ }^{22}$ Czarnowicz 2012a: 249-251.
} 


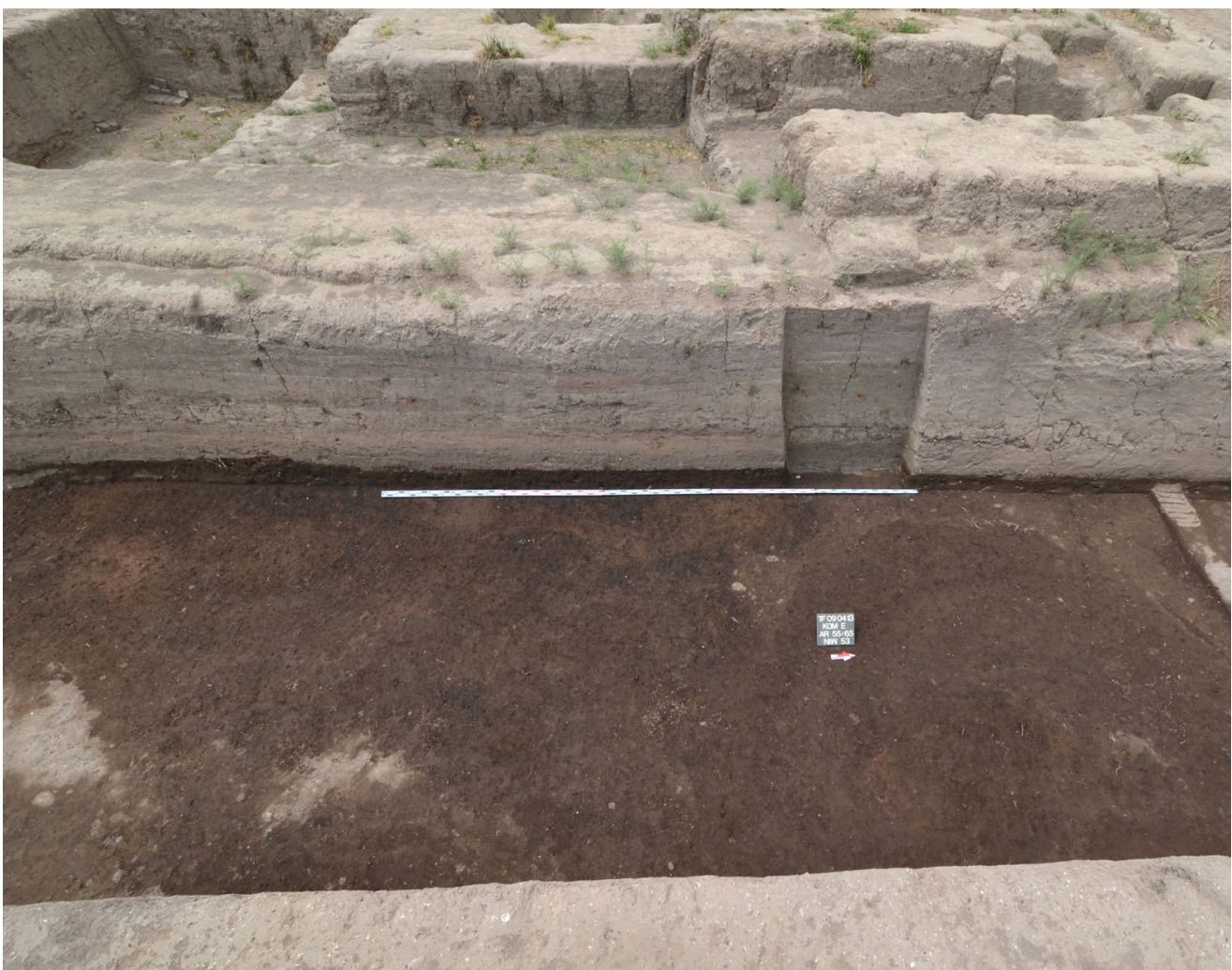

10. A layer of destruction under the mastaba from the Eastern Kom; view from the east (Phot. R. Słaboński).

the turn of Naqada IIIA2/B1, has been presented in several publications. ${ }^{23}$ It is necessary only to mention that this monumental $(16.9 \times 18.1 \mathrm{~m})$ mud-brick structure, and the walls separating mastaba from east, north and south were erected on the above-mentioned burnt layer ending the first Naqadian settlement (Fig. 10) in a similar way as the oldest stage of the administrative-cultic centre was built on the ruins of Naqadian residence. The big storage from the Central Kom was also rebuilt at the same time.

As mentioned above the mastaba was separated from the settlement by high walls. To the north of it, small, very bad executed rooms and workshops were discovered. Despite poor character of this part of the Eastern Kom, the area was abundant in small finds such as clay figurines, various categories of flint and copper tools, and numerous bread moulds. Keeping in mind all these facts, the first preliminary hypothesis arose that this part of the site should be regarded as a prototype for the later estates established for supplying the posthumous cult.

To the south-east of this monumental edifice, a few smaller mastaba-graves, from the first part of Naqada IIIB, were uncovered.

23 E.g. Ciałowicz, Dębowska-Ludwin 2013b. 


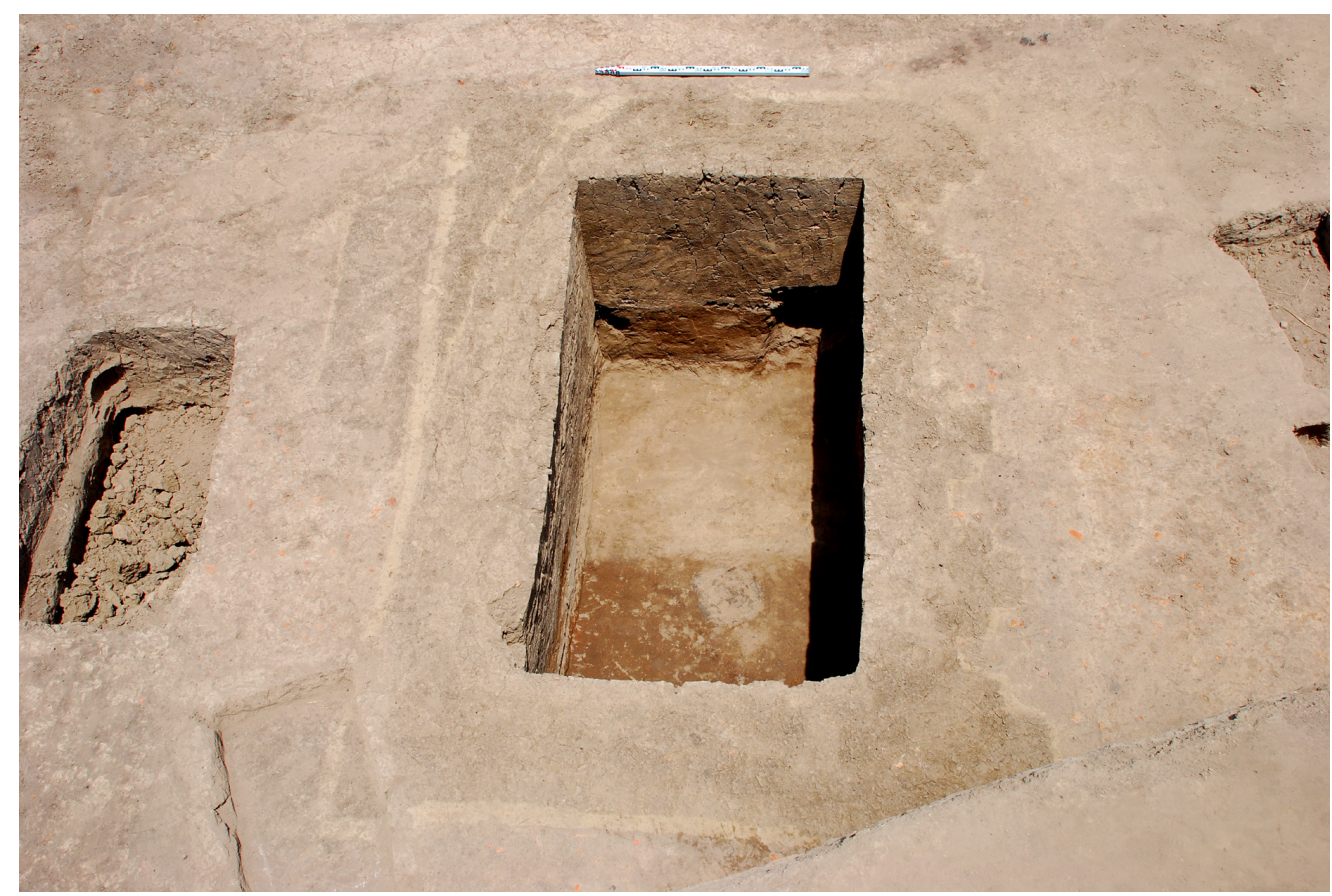

11. Small mastaba no. 63; view from the south (Phot. R. Słaboński).

At least from the beginning of Naqada IIIB, Tell el-Farkha was related with one of the Upper Egyptians proto-kingdoms. This is evidenced by the discovery of a badly made clay cylinder seal discovered at the Central Kom and dated to this period, with Horus and Nebty names on it. ${ }^{24}$ The seal belonged to a lower rank official related to an important political centre. It also means that as early as the Naqada IIIB period both names were popular and that even such a seal enabled identification of the addressee.

The mastaba was very soon abandoned. Later burials were located to the south-east and just above it. A small mastaba-grave no. 63 (Fig. 11) and a two-chamber grave no. 69 were located on the wall separating the mastaba from the south. ${ }^{25}$ Both graves are very precisely dated to the reign of Iry-Hor (middle Naqada IIIB). One wine jar from grave no. 69 bears his name (Fig. 13) and pottery vessels from both graves belong to the same types.

One of the most spectacular discoveries at Tell el-Farkha was made in the poor settlement on the Eastern Kom, where the remains of two gold figures were excavated. ${ }^{26}$ Along with the figures, two large flint knives as well as a necklace of ostrich egg shells and carnelian

\footnotetext{
24 Ciałowicz 2011b: 22.

25 Dębowska-Ludwin 2012: 65.

${ }^{26}$ Chłodnicki, Ciałowicz 2007.
} 


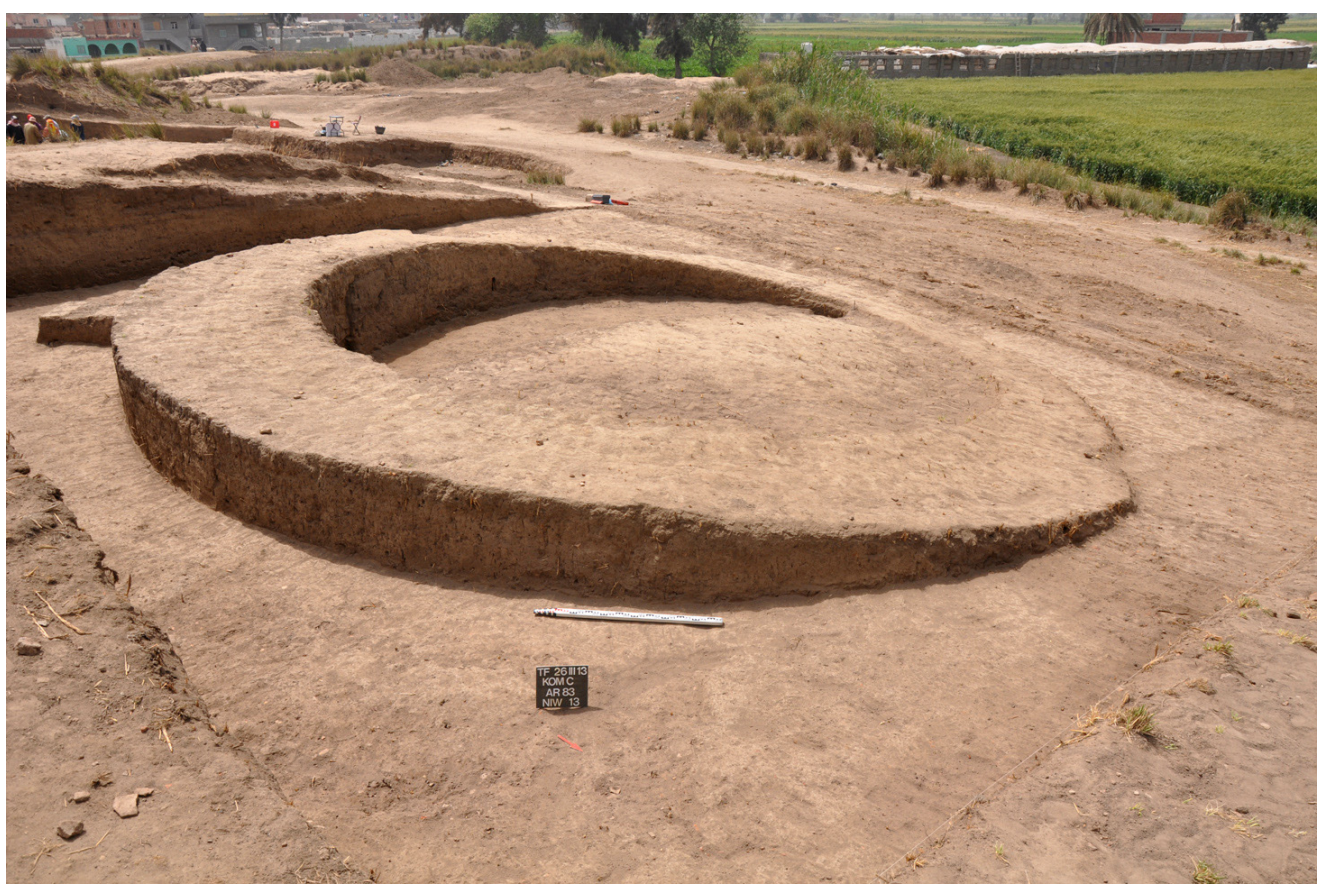

12. The great round silo from the Central Kom; view from the north-east (Phot. R. Słaboński).

beads were put there. The deposit was discovered in a structure that had already been ruined when the items were hidden. The treasure was placed alongside the northern wall, and all the objects were positioned parallel to one another. The whole assemblage was probably originally wrapped in some material. The find's context suggests that the objects in question were hidden in the structure and that this was not the place where they had originally been stored or exhibited. On the basis of ceramics encountered directly over the golden statuettes and in adjacent rooms, we may suggest that they were deposited in the middle of the Naqada IIIB period, so very near the time when the above-mentioned graves were erected.

No layer of destruction separating the monumental mastaba and the surrounding wall from the most recent constructions was recorded. However, the fact that a settlement and later graves were built over the mastaba suggest discontinuity of habitation at the site. This supposition is confirmed by the deposit of golden figurines, never recovered in the past, which seems to indicate that the people who had hidden the figurines never returned to Tell el-Farkha and were replaced by completely new inhabitants probably from another part of Egypt. However, this time the arrival of a new population was not connected with the destruction of the Tell el-Farkha settlement; the inhabitants probably escaped and new settlers took over the settlement without destroying it. In such a situation we would have the third group of Naqadians. All thus far available information indicates that this event 
could have taken place in the time of Iry-Hor, which is attested by the three inscriptions engraved on vessels discovered at Tell el-Farkha. This third group of Naqadians should most probably be regarded as enemies of the second one - independent or under the control of another proto-kingdom.

Nevertheless, no cultural difference between the second and third group of Naqadians is visible. The third group could even be regarded as continuators of the second one. Mastaba-graves were still used and the pottery and other artefacts did not change. The newcomers rebuilt and still used the monumental storage from the Central Kom, as well as the administrative-cultic centre from the Western one. Certainly, the last stage of the complex, and probably the middle one as well, were constructed by the third group of inhabitants. The votive deposits discovered in two chapels of administrative-cultic centre demonstrate strong stylistic and ideological connections with deposits known from Upper Egypt. ${ }^{27}$

In the middle of the First Dynasty, Tell el-Farkha lost its importance and changed its role. The administrative-cultic centre and the entire Western Kom were abandoned. However, at the same time a great round building (Fig. 12) was erected on the Central Kom and existed until the end of the Third Dynasty. ${ }^{28}$ It was almost $11 \mathrm{~m}$ in diameter, and should be interpreted as a great silo, similar to those known from Early Dynastic iconography. Such tower-constructions were used for collecting grain and other commodities for the ruler's court or for the posthumous cult. It is intriguing that many human remains were found around the building. However, no grave was recognised there and the bones recorded during excavations were scattered. They belong to more than one person. It is difficult to interpret such a situation, but maybe at the turn of the First Dynasty some violent circumstances took place at Tell el-Farkha.

At the same time, changes can be seen at the Tell el-Farkha cemetery. Some of the Protodynastic mastabas were cut by later burials. For instance: grave no. 100, dated to Naqada IIIB, is intersected by grave no. 108 from the First/Second Dynasty; south-western corner of the above-mentioned grave no. 63 (cf. Fig. 11) was cut by another burial (no. 71) dated to the second half of the First Dynasty. Therefore these two Dynastic graves were founded when the two-meter high grave no. 63 and grave no. 100 had already been forgotten, and covered with layers of erosion and mud. This could also be proof that new settlers came at the end of the First Dynasty. At that time the Delta witnessed strong local cultural differences, which could have resulted from different traditions connected with the place of origin of the new settlers and from internal Egyptian migration. This is corroborated by evidence from Tell el-Murra. At that site, clay coffins were quite popular in the Early Dynastic cemetery, ${ }^{29}$ while no coffins were discovered at the Tell el-Farkha cemetery dated to the same period.

\footnotetext{
27 Ciałowicz 2012c.

${ }_{28}$ Chłodnicki, Ciałowicz 2016: 240-241.

29 Jucha 2013: 56.
} 
The reasons behind the transformations that took place at the end of the First Dynasty are probably completely different from those responsible for previous changes. The appearance of a new group of people during the late Predynastic and Protodynastic times could be explained as the result of competition - in various fields - between the main power centres. The most important domain of competition could be control over trade routes leading to the Sinai and Southern Levant. On the other hand, the changes in the second part of the First Dynasty could be connected with some economic or religious unrest. Unfortunately our knowledge about the reign of the last kings of the First and almost all of the Second Dynasty is very limited and the reconstruction of the history of this time is still far from satisfactory. It is quite possible that internal migration and the changes connected with it could have taken place in those times. Tell el-Farkha lost its political importance then, but still had economical significance, as a local centre. The land trade routes leading to the Near East were probably rarely used or even abandoned. At that time, sea trade grew in importance. Therefore, the centres located near main branches of the Nile, as p.ex. Mendes, were prospering, while those situated on land routes were diminishing. It is then possible that in the middle of the First Dynasty the local elite and other members of society connected with them (p. ex. artisans, servants) moved from Tell el-Farkha to another town - Mendes seems to be the best candidate. They were replaced by new settlers, from other place in the Delta, or even from Middle and Upper Egypt. The base of their economy was agriculture. The crops, before being exported, were collected in the big silo at the Central Kom, supervised by high rank official, as is proved by a big stamp-seal with hieroglyphic sign discovered in the direct vicinity of the silo. ${ }^{30}$

Summarising, it is necessary to stress certain points. First of all, it seems that Lower Egyptian society was much more stratified than it was previously supposed. At its head stood a local elite, which supervised trade with the East and South and established the basis for future relations. The first Naqadians came to Tell el-Farkha as tradesmen or settlers, but with the permission of the Lower Egyptian elite. In all, three groups of Naqadians connected with different political centres probably settled at Tell el-Farkha during the Late Predynastic and Protodynastic times. Further changes, related to the inner migration within Delta and shift in the economy of the site, took place during the second part of the First Dynasty.

The mastaba as a grave type was introduced in the Delta, possibly together with the idea of setting up the foundations or estates for a posthumous cult. People working on monumental constructions were, at least from the times of Naqada IID, provided with beer, so the organisation of work had to be at a high level. It is difficult to decide whether this key progressive step in the organisation of work should be considered as a contribution of the Lower Egyptians or Naqadians, as both societies introduced similar solutions simultaneously.

${ }^{30}$ Chłodnicki, Ciałowicz 2016: 241-242. 
13. The jar with name of Iry-Hor from grave no. 69 (Phot. R. Słaboński).
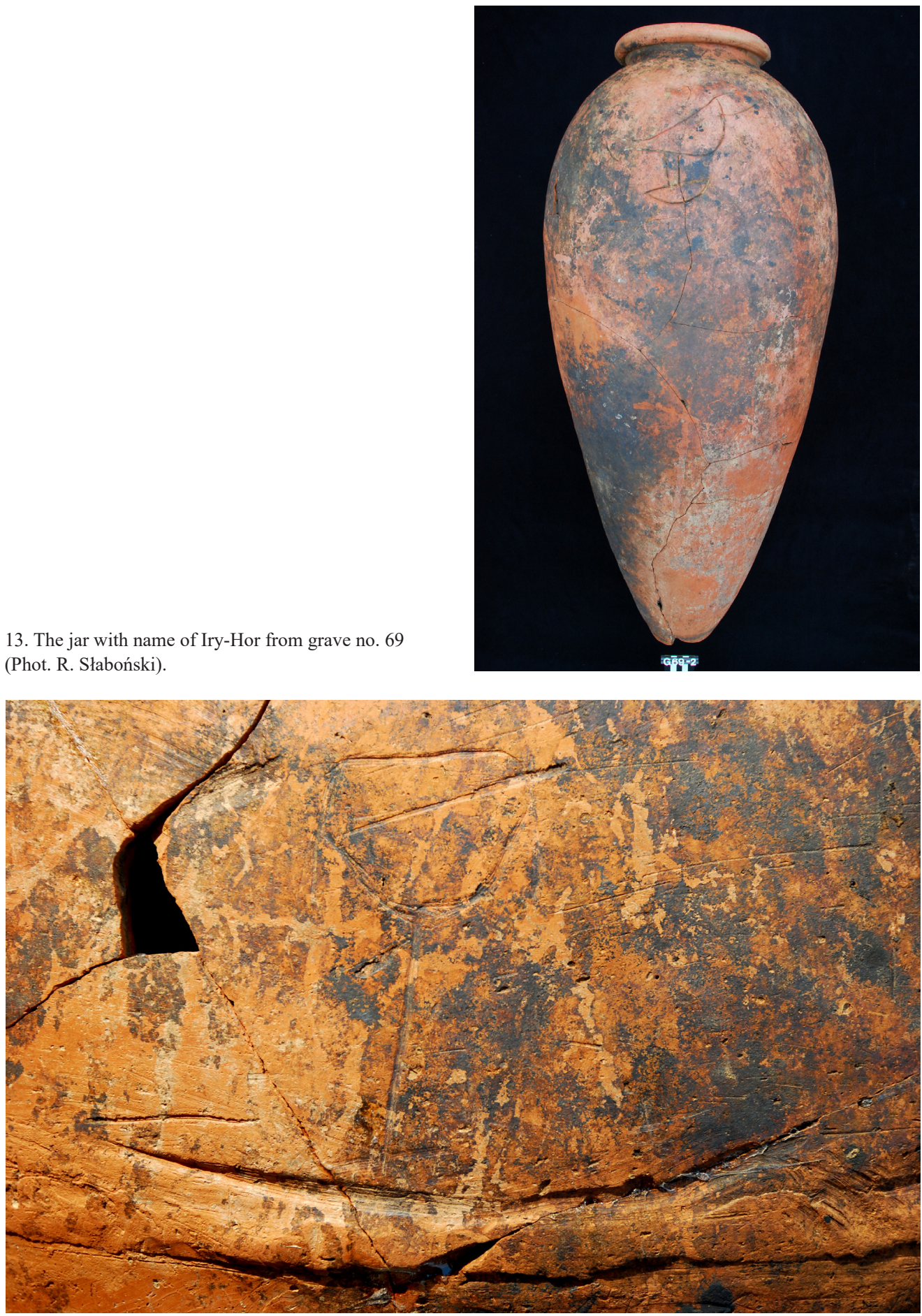

14. Mace on boat engraved on jar from grave no. 69 (Phot. R. Słaboński). 
The phase between Naqada IIIA and middle of IIIB seems to have been a period of competition between the most influential Naqadian proto-kingdoms, as proved by the burnt Naqadian residence (Naqada IIIA1) or hidden golden figurines (middle Naqada IIIB). Three inscriptions with the name of Iry-Hor were found at Tell el-Farkha (Fig. 13). He was previously known mainly from Abydos, but now we have proof that Iry-Hor had at least some connection with the Delta and, more probably, that he ruled over the whole of Egypt. Few others could have reigned earlier but it is hard to determine whether their power stretched over the whole country or, which seems more likely, only over a part of it.

In this context it is important to mention the engraving on a jar from grave no. 69 (in which inscription naming Iry-Hor was discovered, too), representing a mace - an evident symbol of power - standing on a boat (Fig. 14). In grave no. 91, two probably royal names were discovered on jars dated to the beginning of Naqada IIIB (before Iry-Hor). Particularly interesting is the one with two maces - inside a serekh and one outside. Three similar serekhs, are known and all from Lower Egypt, and only one potsherd with a fragment of similar engraving comes from Abydos. ${ }^{31}$ This could be then proof of the existence of a local Lower Egyptian ruler residing in the Eastern Delta. On the other hand the maces could be considered also as symbols of conquered territory.

From the times of Lower Egyptian culture (at least contemporary with Naqada IIB), until the middle of the First Dynasty, Tell el-Farkha was one of the most important towns, not only in the Eastern Delta. An administrative-cultic centre was located there at the beginning of the historical period, which means that Tell el-Farkha was at least a capital of a part of the Eastern Delta, or maybe even of the entire region. The connection of this centre with proto-kings and later with the royal court is confirmed by the golden figurines and some objects from a votive deposit found in the western chapel of the administrative-cultic centre. This should not come as a surprise since the Eastern Delta was a much more important area during the formation of the Egyptian state than was previously supposed.

\section{Acknowledgments}

The article is a result of researches financed by the Polish National Science Centre (project no. 2014/13/B/HS3/04976).

\section{References}

Adams, B. 1996: Elite Graves at Hierakonpolis, [in:] Spencer, A.J. (Ed.), Aspects of Early Egypt, London, 1-15

Brink, E.C.M. van den 1988: The Amsterdam University Survey Expedition to the north-eastern Nile Delta (1984-1986), [in:] Brink, E.C.M. van den (Ed.), The Archaeology of the Nile Delta. Problems and Priorities, Amsterdam, 65-114

Chłodnicki, M., Ciałowicz, K.M. 2007: Golden figures from Tell el-Farkha, SAAC 10, 7-21

31 Jucha 2012: 635. 
Chłodnicki, M., Ciałowicz, K.M. 2016: Tell el-Farkha: Archaeological fieldwork 2014-2015, PAM XXV, 227-254

Chłodnicki, M., Ciałowicz, K.M., Mączyńska, A. (Eds) 2012: Tell el-Farkha I. Excavations 1998-2011, Poznań-Kraków

Chłodnicki, M., Fattovich, R., Salvatori, S. 1991: Italian Excavations in the Nile Delta: Fresh Data and New Hypotheses on the $4^{\text {th }}$ Millennium Cultural Development of Egyptian Prehistory, RivArch 15, 5-33

Chłodnicki, M., Fattovich, R., Salvatori, S. 1992: The Italian Archaeological Mission of the C.S.R.L. - Venice to the Eastern Nile Delta: A preliminary report of the 1987-1988 field season, CRIPEL 14, 45-62

Chłodnicki, M., Geming, M.M. 2012: Lower Egyptian settlement on the Central Kom, [in:] Chłodnicki, M., Ciałowicz, K.M., Mączyńska, A. (Eds), Tell el-Farkha I. Excavations 1998-2011, Poznań-Kraków, 89-104

Ciałowicz, K.M. 2011a: The Early Dynastic administrative-cultic centre at Tell el-Farkha, [in:] Friedman, R.N., Fiske, P.N. (Eds), Egypt at Its Origins 3: Proceedings of the Third International Conference "Origin of the State. Predynastic and Early Dynastic Egypt”, London, 27th July-1 st August 2008, OLA 205, Leuven, 763-800

Ciałowicz, K.M. 2011b: Fantastic creatures and cobras from Tell el-Farkha, SAAC 15, 11-27 Ciałowicz, K.M. 2012a: Lower Egyptian settlement on the Western Kom, [in:] Chłodnicki, M., Ciałowicz, K.M., Mączyńska, A. (Eds), Tell el-Farkha I. Excavations 1998-2011, Poznań-Kraków, 149-162

Ciałowicz, K.M. 2012b: Protodynastic and Early Dynastic settlement on the Western Kom, [in:] Chłodnicki, M., Ciałowicz, K.M., Mączyńska, A. (Eds), Tell el-Farkha I. Excavations 1998-2011, Poznań-Kraków, 163-180

Ciałowicz, K.M., 2012c: Early Egyptian objects of art, [in:] Chłodnicki, M., Ciałowicz, K.M., Mączyńska, A. (Eds), Tell el-Farkha I. Excavations 1998-2011, Poznań-Kraków, 201-243

Ciałowicz, K.M., Dębowska-Ludwin, J. 2013a: Tell el-Farkha and its implications for understanding the earliest architecture of Lower Egypt, $S A A C$ 17, 25-40

Ciałowicz, K.M., Dębowska-Ludwin, J. 2013b: The Origin of Egyptian Mastabas in the Light of Research at Tell el-Farkha, EtudTrav XXVI/1, 153-162

Czarnowicz, M. 2012a: Southern Levantine imports and imitations, [in:] Chłodnicki, M., Ciałowicz, K.M., Mączyńska, A. (Eds), Tell el-Farkha I. Excavations 1998-2011, Poznań-Kraków, 245-265

Czarnowicz, M. 2012b: Copper tools, [in:] Chłodnicki, M., Ciałowicz, K.M., Mączyńska, A. (Eds), Tell el-Farkha I. Excavations 1998-2011, Poznań-Kraków, 345-355

Dębowska-Ludwin, J. 2012: The cemetery, [in:] Chłodnicki, M., Ciałowicz, K.M., Mączyńska, A. (Eds), Tell el-Farkha I. Excavations 1998-2011, Poznań-Kraków, 53-75

Dreyer, G., Engel, E.-M., Hartung, U., Hikade, T., Köhler, E.Ch., Pumpenmeier, F. 1996: Umm el-Qaab. Nachuntersuchungen im frühzeitlichen Königsfriedhof 7./8. Vorbericht, MDAIK 52, 11-81 
Dreyer, G., Hartung, U., Pumpenmeier, F. 1993: Umm el-Qaab. Nachuntersuchungen im frühzeitlichen Königsfriedhof 5./6. Vorbericht, MDAIK 49, 23-62

Friedman, R.N. 2008: The Cemeteries of Hierakonpolis, Archéo-Nil 18, 8-29

Friedman, R.N. 2009: Hierakonpolis Locality HK29A: The Predynastic Ceremonial Center Revisited, JARCE 45, 79-103

Jucha, M.A. 2012: New Protodynastic serekhs from the Nile Delta: the case of finds from Tell el-Farkha, PAM XXI, 625-641

Jucha, M.A. 2013: Tell el-Murra - results of survey and prospects for research, $S A A C$ 17, 53-61

Jucha, M.A., Bąk-Pryc, G., Małecka-Drozd, N., Kazimierczak, M., Ownby, M.F., Mądrzyk, K., Pankowska, A., Woźniak, B., Abłamowicz, R. 2016: Polish Excavations at Tell el-Murra in the Nile Delta. Preliminary Report 2013-2015, Archeologia (V) LXV, 85-146

Jucha, M.A., Buszek, A. 2011: Tell el-Murra (northeastern Nile Delta survey). Season 2008, PAM XX, 177-182

Rizkana, I., Seeher, J. 1989: Maadi III. The Non-Lithic Small Finds and the Structural Remains of the Predynastic Settlement, ArchVer 80, Mainz a/Rhein

Seeher, J. 1990: Maadi - eine prädynastische Kulturgruppe zwischen Oberägypten und Palästina, Praehistorische Zeitschrift 65/1, 123-156 


\section{ÉTUDES et TRAVAUX XXX / 2017}

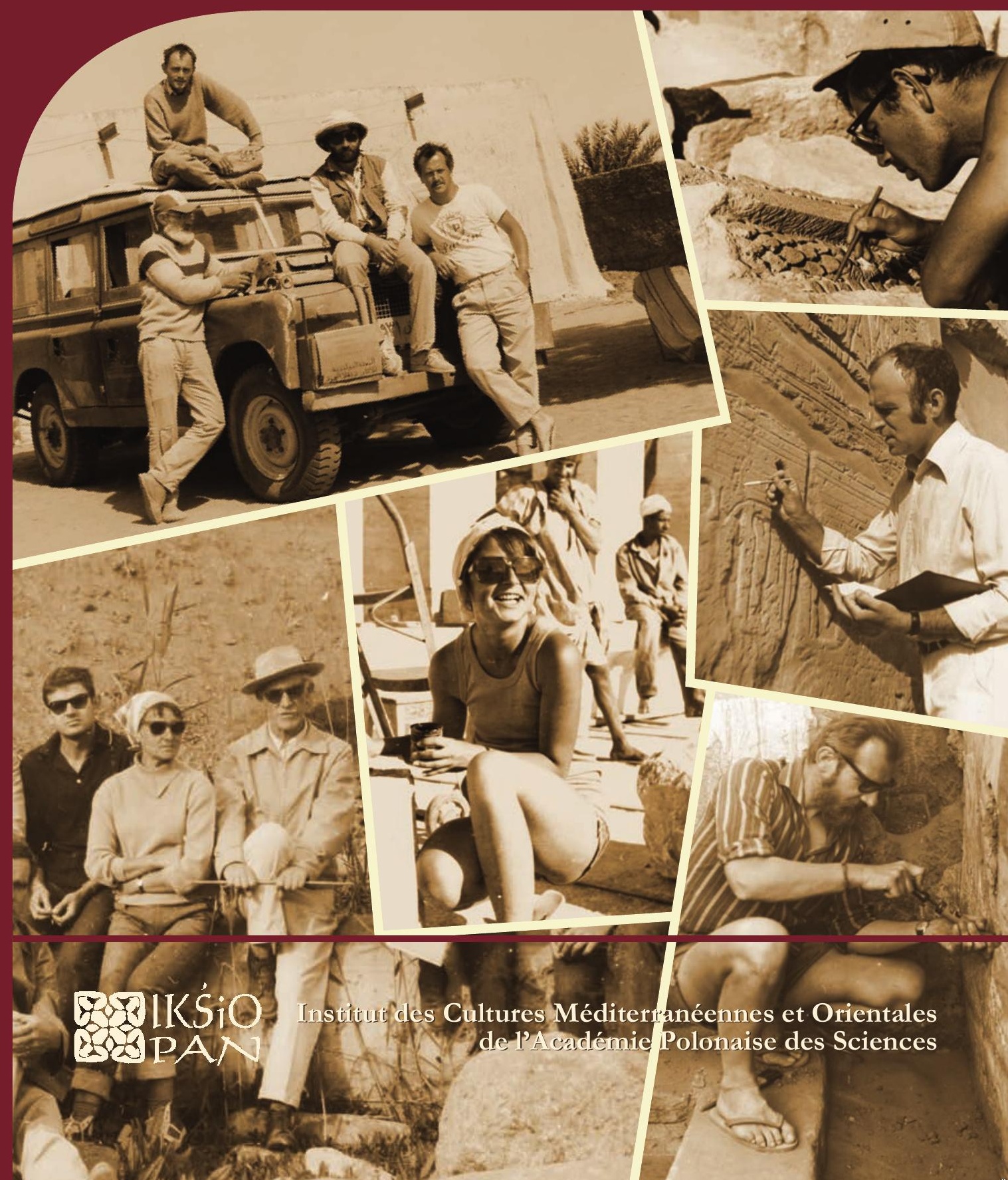




\title{
COMITÉ DE RÉDACTION SCIENTIFIQUE
}

Maciej Makowski - rédacteur en chef

Jadwiga Iwaszczuk - rédacteur et sécretaire de la rédaction

Mariusz Drzewiecki - rédacteur

Maciej G. Witkowski - rédacteur

\section{CONSEIL SCIENTIFIQUE DU JOURNAL}

M. Kobusiewicz (IAE PAS, Warszawa), E. Laskowska-Kusztal (IMOC PAS, Warszawa),

D. Michaelides (University of Cyprus, Nicosia),

J.Ch. Moretti (IRAA-MOM, Université de Lyon 2/CNRS),

D. Raue (Ägyptisches Museum der Universität Leipzig), P. Reynolds (ICREA, Barcelona),

D. Welsby (British Museum, London)

\section{COMITÉ SCIENTIFIQUE DE LECTURE}

J. Holaubek (Institut für Ägyptologie, Wien), S. Ikram (AUC, Cairo),

K. Innemée (Universiteit Leiden), J. McKenzie (Faculty of Oriental Studies, University of Oxford),

N. Strudwick (University of Cambridge), A. Loprieno-Gnirs (Universität Basel),

Ch.E. Loeben (Museen für Kulturgeschichte, Hannover), Y. Tristant (Macquarie University, Sydney),

V.W.J. van Gerven Oei (University of Aberdeen), A. Peignard-Giros (HiSoMA-MOM, Université de Lyon 2/CNRS), J.A. Ostrowski, E. Papuci-Władyka, J. Śliwa (IA JU, Kraków), R. Czerner (WUST, Wrocław), A. Ćwiek (IA AMU, Poznań), M. Wiewióra (IA NCU, Toruń), K. Domżalski

(IAE PAS, Warszawa), K.O. Kuraszkiewicz (DE FOS UW), M. Barwik, P. Bieliński, P. Dyczek, W. Godlewski, D. Ławecka, S. Rzepka, J. Żelazowski, M. Gawlikowski, J. Młynarczyk, A. Niwiński, T. Sarnowski, D. Szeląg, T. Waliszewski (IA UW, Warszawa)

\section{RÉDACTEUR THÉMATIQUE DU VOLUME \\ Barbara Lichocka}

\author{
AIDE RÉDACTION TECHNIQUE \\ Dorota Dobrzyńska, Mariusz Drzewiecki
}

REVUE DES TEXTES ANGLAIS

Jo Harper 
ÉTUDES et TRAVAUX XXX 
INSTYTUT KULTUR ŚRÓDZIEMNOMORSKICH I ORIENTALNYCH POLSKIEJ AKADEMII NAUK

\section{STUDIA i PRACE}

XXX

\section{Ro IKŚSiO \\ ESA PAN}

WARSZAWA

2017 
INSTITUT DES CULTURES MÉDITERRANÉENNES ET ORIENTALES DE L'ACADÉMIE POLONAISE DES SCIENCES

\section{ÉTUDES et TRAVAUX}

XXX

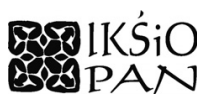

VARSOVIE

2017 
Publication scientifique financée dans le cadre du programme du Ministre de la Science et de l'Éducation Supérieure

« Programme National de Développement de l’Humanistique » pour les années 2016-2021 (projet no 3bH 150099 83)

\title{
HARODOWY PROGRAM ROZWOJU HUMANISTYKI
}

\author{
Copyright (C) \\ Instytut Kultur Śródziemnomorskich i Orientalnych PAN \\ et les Auteurs \\ Warszawa 2017
}

\author{
ISSN 2084-6762 \\ (avant $2011: 0079-3566$ ) \\ e-ISSN 2449-9579 \\ Version première en papier, imprimée en Pologne - 150 copies \\ Version électronique accessible sur \\ http://www.etudesettravaux.iksiopan.pl
}

Édition: Polskie Towarzystwo Historyczne et Wydawnictwo Neriton, Warszawa

Conception générale de couverture : J. Iwaszczuk

Photos de couverture : En haut, à gauche. Vieille Dongola 1991, S. Jakobielski

(debout à gauche), K. Pluskota (debout à droite), B. Żurawski (assis sur le camion)

et P. Wierzbicki (assis sur le camion) (de la collection de B. Żurawski)

En haut, à droite. Palmyre 1964, M. Marciniak au travail (phot. A. Dziewanowski)

Au centre. E. Laskowska-Kusztal au travail (de la collection de E. Laskowska-Kusztal)

En bas, à gauche. Tell Atrib 1962 ; de gauche : T. Biniewski, M. Marciniak, K. Kołodziejczyk,

K. Michałowski, A. Ostrasz, S. Jakobielski et S. Jasiewicz devant eux

(de la collection de IKŚSiO PAN).

En bas, à droite. Vieille Dongola 1976, S. Jakobielski nettoyant le mur (phot. M. Steinborn).

Au centre, à droite, K. Myśliwiec en train des travaux de documentation (de la collection de IKŚiO PAN) 


\section{Table des matières}

BARBARA LICHOCKA

Ergon agathon

Hartwig Altenmüller

$\mathrm{Zu}$ den Feindbildern auf den Zauberstäben des Mittleren Reiches und der Zweiten

Zwischenzeit

Nathalie Beaux

Des $m s w n s w$ de Thoutmosis III à Deir el-Bahari

Briant Bohleke, Nigel Strudwick

A Label for Opening of the Mouth Implements from the Burial of Senneferi (TT99)

and Remarks on the Ritual

Rosa Maria Bonacasa Carra, Nicola Bonacasa

Nuovi dati sugli edifici termali di Sabratha

EDWARD BROVARSKI

A Fragmentary Carrying Chair Scene in Salt Lake City, Utah

Julia Burdajewicz

Wall Painting Decoration from the North-West Church in Hippos-Sussita

of the Decapolis

Mariusz BURDAJEWICZ

From Pagan Temple to Church in Late Antiquity Palestine. A View from

Hippos-Sussita

MAREK ChlodNicki

Early Dynastic Bead Workshops at the Central Kom of Tell el-Farkha.

Patryk ChudziK, Mariusz Caban

Observations on the Architecture of the Tomb of Horhotep in Western Thebes

Krzysztof M. Cialowicz

New Discoveries at Tell el-Farkha and the Beginnings of the Egyptian State.

Amr EL-TiebI

Four Wooden New Kingdom Female Statuettes in the Egyptian Museum, Cairo 


\section{Naguib KanaWATI}

Ritual Marriage Alliances and Consolidation of Power in Middle Egypt during the Middle Kingdom

Adam Łajtar, Jolanta Mlynarczyk

A Faction Acclamation Incised on a Pithos Found Near the North-West Church at Hippos (Sussita)

Adam ŁaJTAR, Grzegorz OchaŁa

Two Private Prayers in Wall Inscriptions in the Faras Cathedral

Adam Łajtar, Anna Poludnikiewicz

Medicinal Vessels from Tell Atrib (Egypt)

JaCeK Michniewicz, Jolanta MlynarczyK

Petrographic Variability of the Fabrics of Wine Jars from Sha'ar-Ha Amakim as a Reflection of Differences in Their Provenance and Chronology

Iwona ModrzewsKa-PianetTI

Les importations d'amphores Dressel 20 en Gaule Cisalpine

Arthur SEgal

Samaria-Sebaste. Portrait of a polis in the Heart of Samaria 409

JOACHIM ŚLIWA

The Motif of a 'Blind Harper' in an Unexpected Place

MONIKA WIĘCH

Searching for the Kitchen in the Early Roman Phase of the 'Hellenistic' House at Nea Paphos (Cyprus)

Abréviations 
THE VOLUME IS PUBLISHED TO CELEBRATE

THE $60^{\text {TH }}$ ANNIVERSARY

OF THE ESTABLISHMENT OF

THE RESEARCH CENTRE FOR MEDITERRANEAN ARCHAEOLOGY POLISH ACADEMY OF SCIENCES

FOUNDED IN 1956

WHOSE MISSION IS CONTINUED BY

THE INSTITUTE OF MEDITERRANEAN AND ORIENTAL CULTURES

OF THE POLISH ACADEMY OF SCIENCES 